\title{
Tingkat Literasi Keuangan Syariah Di Kalangan UMKM Dan Dampaknya Terhadap Perkembangan Usaha
}

\author{
Diana Djuwita \\ Ayus Ahmad Yusuf \\ Dosen Jurusan Perbankan Syariah Fakultas Syariah dan Ekonomi Islam \\ IAIN Syekh Nurjati Cirebon \\ Email: dianadjuwita12@gmail.com
}

\begin{abstract}
Abstrak
Rendahnya kinerja UMKM di Indonesia salah satunya disebabkan oleh kurangnya akses pemodalan. Hal ini dapat disebabkan oleh minimnya pengetahuan dan pemahaman UMKM terhadap keberadaan lembaga keuangan, yang dikenal dengan sebutan literasi keuangan. Berdasarkan hasil survey yang dilakukan Otorisasi Jasa Keuangan (OJK) pada tahun 2013 bahwa tingkat literasi keuangan penduduk Indonesia terbagi menjadi empat kategori, yaitu well literate (21,84\%), sufficient literate (75,69\%), less literate (2,06\%), dan not literate $(0,41 \%)$. Saat ini keuangan syariah makin berkembang pesat dengan banyaknya lembaga-lembaga keuangan syariah yang menawarkan produk dan jasa keuangan berlandaskan syariat Islam. Tetapi faktanya keuangan syariah hingga saat ini masih memiliki pangsa pasar yang rendah di negara Indonesia yang mayoritas penduduknya muslim. Tujuan penelitian ini adalah untuk mengetahui tingkat literasi keuangan syariah di kalangan UMKM khususnya pedagang kaki lima di kawasan Masjid Raya At-Taqwa Kota Cirebon, untuk mengetahui faktor-faktor yang mempengaruhi tingkat literasi keuangan syariah di kalangan UMKM di kawasan Masjid Raya At-Taqwa Kota Cirebon, dan untuk mengetahui dampak tingkat literasi keuangan syariah terhadap perkembangan usaha UMKM di kawasan Masjid Raya At-Taqwa Kota Cirebon.

Metode penelitian yang digunakan dalam penelitian ini adalah descriptive survey dan explanatory surve. Jumlah responden 31 UMKM, yang 87 persen adalah pedagang kaki lima. Pengumpulan data menggunakan instrumen penelitian berupa kuesioner yang telah diuji validitas dan reliabilitasnya. Data hasil kuesioner diuji asumsi klasik (uji normalitas, heterokedastisitas, multikolinearitas, dan autokorelasi). Analisis deskriptif dilakukan terhadap data hasil penelitian, kemudian dilakukan uji regresi berganda untuk mengetahui hubungan antar variabel yang diteliti.

Hasil penelitian yang diperoleh adalah hanya variabel lama usaha dan jumlah karyawan yang berpengaruh signifikan terhadap financial knowledge. Seluruh variabel demografi (lokasi, usia, jenis kelamin, pendidikan, jenis usaha, lama usaha, modal awal, sumber modal, pendapatan, dan jumlah karyawan) tidak mempengaruhi financial behaviour dan financial attitude para pedagang kaki lima. Hanya financial behaviour saja yang mempengaruhi perkembangan usaha para pedagang kaki lima, sementara financial knowledge dan financial attitude tidak mempengaruhi perkembangan usaha.
\end{abstract}

Kata Kunci: Literasi Keuangan Syariah, UMKM, Pedagang Kaki Lima, Perkembangan Usaha 


\begin{abstract}
The low performance of MSMEs in Indonesia is caused by the lack of access to capital. This can be caused by the lack of knowledge and understanding of MSMEs on the existence of financial institutions, known as financial literacy. Based on the results of a survey conducted by the Financial Services Authority (OJK) in 2013 that the level of financial lteracy of Indonesian population is divided into four categories, namely well literate (21,84\%), sufficient literate (75,69\%), less literate (2,06\%), and not literate $(0,41 \%)$. Currently sharia finance is growing rapidly with the number of Islamic financial institutions that offer products and financial services based on Islamic Sharia. But the fact that Islamic finance to date still has a low market share in the majority moeslem country of Indonesia. The purpose of this study is to determine the level of Islamic financial literacy among SMEs, especially street vendors in the area of At-Taqwa Mosque Cirebon City, to determine the factors that affect the level of Sharia financial literacy among MSMEs in the area At-Taqwa Mosque Cirebon City, and to know the impact of the level of sharia financial literacy on the development of SMEs in the area of At-Taqwa Mosque Cirebon City.

The research methode used in this descriptive survey and explanatory survey. Number of respondents 31 SMEs, of which $87 \%$ are street vendors. Data collection using research instruments in the form of questionnaires that have been tested for validity and reliability. The results of the questionnaires tested the classical assumptions (test of normality, heterocedasticity, multicollinearity, and autocorrelation). Descriptive analysis conducted on the data of research results, then multiple regression test to determine the relationship between variables studied.

The result of the research is only the old variable of business and the number of employees that have significant effect on the financial knowledge. All demographic variables (location, age, gender, education, type of business, length of business, initial capital, source of capital, income, and number of employees) do not affect the financial behaviour and financial attitude of street traders. Only financial behaviour alone affects the business development of street traders, while financial knowledge and financial attitude does not affect business development.
\end{abstract}

Keywords: Sharia Financial Literacy, SMEs, Street Traders, Business Development 


\section{Pendahuluan}

Usaha Mikro, Kecil, dan Menengah (UMKM) dapat menjadi penopang perekonomian suatu negara karena UMKM mampu menyerap banyak tenaga kerja. Sektor UMKM membantu penyerapan tenaga kerja di dalam negeri. Selama periode lima tahun terakhir, tingkat serapan tenaga kerja pada sektor UMKM tumbuh dari 96,99 persen menjadi 97,22 persen. Kamar Dagang dan Industri Indonesia (Kadin) menilai bahwa banyaknya tenaga kerja yang mampu diserap oleh sektor UMKM dapat meningkatkan pendapatan masyarakat. Oleh karena itu, UMKM dianggap memiliki peran strategis dalam mengurangi angka kemiskinan dan pengangguran (www.cnnindonesia.com).

Sektor UMKM tidak hanya memberikan kontribusi dalam hal penyediaan lapangan pekerjaan tetapi berkontribusi pula terhadap produk domestik bruto (PDB) yang semakin menggeliat dalam lima tahun terakhir. Berdasarkan catatan Kementerian Koperasi dan Usaha Kecil Menengah (Kemenkop dan UKM), kontribusi sektor UMKM meningkat dari 57,84 persen menjadi 60,34 persen (http://www.kemenperin.go.id).

Adapun dari 15 subsektor ekonomi kreatif yang dikembangkan, tiga di antaranya tercatat berkontribusi paling besar terhadap PDB, yaitu kuliner sebesar 209 triliun Rupiah atau 32,5 persen, fesyen sebesar 182 triliun Rupiah atau 28,3 persen, dan kerajinan sebesar 93 triliun Rupiah atau 14,4 persen (www.cnnindonesia.com).

Meskipun indikator kontribusi terhadap pembentukan produk domestik bruto (PDB) dan serapan tenaga kerja meningkat, akses sektor UMKM ke rantai pasok produksi global sangat minim. Kontribusi UMKM di Indonesia terhadap rantai pasok global hanya sebesar 0,8 persen. Ini menunjukkan bahwa pengembangan usaha besar tidak melibatkan kontribusi UMKM. Sebagian besar pelaku UMKM tidak memiliki akses dan informasi ke pasar global. (http://www.kemenperin.go.id). Bisnis UMKM memang memiliki beberapa kelemahan dalam beroperasi. Misalnya, kesulitan pemasaran, akses ke sumber pembiayaan yang sangat terbatas, keterbatasan sumber daya manusia (SDM), kesulitan bahan baku, keterbatasan inovasi dan teknologi (http://www.cnnindonesia.com).

Kinerja UMKM di Indonesia masih relatif lebih rendah dibandingkan negara-negara ASEAN lainnya, terutama dalam hal produktivitas, kontribusi ekspor, partisipasi produksi global dan regional serta kontribusi terhadap nilai tambah. Rendahnya daya saing UMKM di Indonesia antara lain disebabkan oleh rendahnya tingkat pendidikan dan keahlian, sulitnya pengurusan perizinan bagi UMKM, kurangnya akses pemodalan, dan kurangnya dukungan infrastruktur (http://bi.go.id).

Salah satu penyebab rendahnya kinerja UMKM adalah karena kurangnya akses pemodalan. Hal ini dapat disebabkan oleh minimnya pengetahuan dan pemahaman UMKM terhadap keberadaan lembaga keuangan. Inilah yang dikenal dengan sebutan literasi keuangan. Berdasarkan hasil survey yang dilakukan Otorisasi Jasa Keuangan (OJK) pada tahun 2013 bahwa tingkat literasi keuangan penduduk Indonesia terbagi menjadi empat kategori, yaitu well literate $(21,84 \%)$, sufficient literate $(75,69 \%)$, less literate $(2,06 \%)$, dan not literate $(0,41 \%) \quad$ (http://www.ojk.go.id). Artinya, baru seperlima dari seluruh masyarakat yang telah teredukasi dan memiliki trust terhadap lembaga 
keuangan serta produk dan jasanya serta memiliki keyakinan dengan baik.

Kategori well literate berarti masyarakat telah teredukasi dan memiliki trust akan lembaga keuangan serta produk dan jasa keuangan, meliputi fitur, manfaat dan risiko, hak dan kewajiban terkait produk dan jasa keuangan, serta terampil dalam menggunakan produk dan jasa keuangan. Sedangkan kategori sufficient literate berarti masyarakat telah terdukasi dan memiliki keyakinan terhadap keberadaan lembaga keuangan serta produk dan jasa keuangan, termasuk fitur, manfaat dan risiko, hak dan kewajiban terkait produk dan jasa keuangan. Kategori less literate artinya masyarakat yang hanya teredukasi tentang lembaga keuangan, produk dan jasa keuangan, dan terakhir kategori not literate yang berarti masyarakat tidak teredukasi dan tidak memiliki trust terhadap lembaga keuangan serta produk dan jasanya, serta tidak terampil dalam menggunakan produk dan jasa keuangan (http://www.ojk.go.id).

Literasi keuangan sangat diperlukan bagi pelaku usaha termasuk UMKM agar UMKM mampu menentukan pilihan dan memanfaatkan produk dan layanan jasa keuangan yang sesuai kebutuhan, memiliki kemampuan dalam melakukan perencanaan keuangan dengan lebih baik, dan terhindar dari aktivitas investasi pada instrumen keuangan yang tidak jelas.

Saat ini keuangan syariah makin berkembang pesat dengan banyaknya lembaga-lembaga keuangan syariah yang menawarkan produk dan jasa keuangan berlandaskan syariat Islam. Keuangan syariah diharapkan dapat menjadi solusi bagi praktikpraktik keuangan yang mengarah pada riba, maysir, dan gharar. Tetapi faktanya keuangan syariah hingga saat ini masih memiliki pangsa pasar yang rendah di negara Indonesia yang mayoritas penduduknya muslim.

Islam adalah agama yang sangat memperhatikan literasi. Di dalam AlQur'an juga banyak disebutkan ayatayat yang berkaitan dengan kekayaan dan keuangan, seperti zakat, shodaqah, wakaf, dan haji yang membutuhkan dana yang cukup besar, sehingga diperlukan perencanaan keuangan. Islam sebagai agama yang mengatur semua aspek kehidupan memberikan arahan dalam hal memperoleh pendapatan atau penghasilan, mengkonsumsinya, menabung, berinvestasi, mengelola harta, dan segala aspek yang berkaitan dengan keuangan (Ahmad Lutfi Abdul Razak dan Rose Abdullah, 2015).

Pengelolaan keuangan sangat penting untuk pengeloaan keuangan personal (pribadi) juga untuk perusahaan, baik skala mikro, kecil, juga menengah.

Salah satu jenis UMKM yang berkembang pesat saat ini adalah pedagang kaki lima. Keberadaan pedagang kaki lima hampir ada di semua wilayah di Indonesia, termasuk di Kota Cirebon. Sejak dibukanya tol Cipali, Cirebon menjadi wilayah yang mudah diakses oleh masyarakat dari Jakarta, Bandung, dan sekitarnya, sehingga kini Cirebon menjadi salah satu destinasi wisata dan kuliner. Hal ini dapat mendorong tumbuhnya UMKM di Cirebon.

Cirebon yang dikenal sebagai kota wali seringkali menjadi salah satu tujuan wisata religi bagi turis domestik. Biasanya para turis domestik ini tak melewatkan kesempatan untuk singgah melaksanakan sholat juga beristirahat sejenak di Masjid Raya At-Taqwa yang merupakan masjid terbesar di Kota Cirebon. Di kawasan Masjid Raya At- 
Taqwa terdapat banyak pedagang kaki lima yang saat ini telah direlokasi oleh Pemerintah Kota Cirebon sehingga nampak lebih rapi, tertib, dan bersih. Para turis domestik dapat menikmati aneka jajanan yang dijual oleh para pedagang kaki lima tersebut. Hal ini seharusnya mendorong para pedagang kaki lima untuk lebih kreatif dan mengembangkan usahanya agar dapat melayani permintaan pasar dengan lebih baik. Tetapi kenyataannya para pedagang kaki lima tidak mengalami perkembangan usaha yang signifikan dari tahun ke tahun. Sejak dulu hingga sekarang, skala dan model usaha dagang yang mereka jalani tidak banyak mengalami perubahan yang disebabkan karena sulitnya mereka dalam mengakses pemodalan.

Lokasi usaha para pedagang kaki lima yang berada di kawasan Masjid Raya At-Taqwa sedikitnya memberikan sentuhan dan pengaruh Islam pada sikap dan perilaku para pedagang kaki lima tersebut. Apalagi Masjid Raya At-Taqwa memiliki Islamic Center yang menjadi pusat kegiatan agama Islam masyarakat Kota Cirebon juga Lembaga zakat yang mengelola zakat produktif.

Berdasarkan latar belakang yang dipaparkan, maka rumusan masalah dapat disusun sebagai berikut:

1. Bagaimana tingkat literasi keuangan syariah di kalangan UMKM khususnya pedagang di kawasan Masjid Raya At-Taqwa Kota Cirebon?

2. Faktor-faktor apa saja yang mempengaruhi tingkat literasi keuangan syariah di kalangan UMKM (Pedagang) di kawasan Masjid Raya At-Taqwa Kota Cirebon?

3. Bagaimana dampak tingkat literasi keuangan syariah pada perkembangan usaha UMKM (pedagang) di kawasan Masjid Raya At-Taqwa Kota Cirebon?

\section{Landasan Teori}

\section{Literasi Keuangan Syariah}

Menurut The Association of Chartered Certified Accountants (2014), konsep literasi keuangan meliputi pengetahuan mengenai konsep keuangan, kemampuan memahami komunikasi tentang konsep keuangan, kecakapan mengelola keuangan pribadi/perusahaan, dan kemampuan melakukan keputusan keuangan dalam situasi tertentu .

Tingkat literasi keuangan penduduk Indonesia dibagi menjadi empat bagian, yakni, Well literate, yakni memiliki pengetahuan dan keyakinan tentang lembaga jasa keuangan serta produk jasa keuangan, termasuk fitur, manfaat dan risiko, hak dan kewajiban terkait produk dan jasa keuangan, serta memiliki keterampilan dalam menggunakan produk dan jasa keuangan, sufficient literate, memiliki pengetahuan dan keyakinan tentang lembaga jasa keuangan serta produk dan jasa keuangan, termasuk fitur, manfaat dan risiko, hak dan kewajiban terkait produk dan jasa keuangan, less literate, hanya memiliki pengetahuan tentang lembaga jasa keuangan, produk dan jasa keuangan, dan not literate, tidak memiliki pengetahuan dan keyakinan terhadap lembaga jasa keuangan serta produk dan jasa keuangan, serta tidak memiliki keterampilan dalam menggunakan produk dan jasa keuangan. Literasi Keuangan memberikan manfaat, seperti mampu memilih dan memanfaatkan produk dan layanan jasa keuangan yang sesuai kebutuhan, memiliki kemampuan dalam melakukan perencanaan keuangan dengan lebih baik, dan terhindar dari aktivitas 
investasi pada instrumen keuangan yang tidak jelas (www.ojk.go.id).

Literasi keuangan syariah adalah perluasan dari literasi keuangan dengan elemen-elemen yang sesuai syariat Islam didalamnya. Literasi keuangan syariah meliputi banyak aspek dalam keuangan, diantaranya pengelolaan uang dan harta (seperti menabung untuk hari tua dan dana darurat untuk digunakan sewaktu-waktu), aspek perencanaan keuangan seperti dana pensiun, investasi, dan asuransi. Ada juga aspek bantuan sosial seperti wakaf, infaq, dan shadaqah.aspek lainnya adalah tentang zakat dan warisan.

Beberapa indikator yang dapat digunakan untuk menilai tingkat literasi keuangan syariah adalah kepemilikan rekening di lembaga keuangan syariah, pemahaman tentang produk dan jasa serta akad-akad syariah, pengetahuan tentang bagi hasil, dan jaminan.

Ada beberapa dimensi dalam literasi keuangan diantaranya financial knowledge (pengetahuan keuangan), financial behaviour (perilaku keuangan), dan financial attitude (sikap keuangan).

Financial knowledge adalah edukasi mengenai tata cara pengelolaan keuangan pribadi untuk menghadapi masa depan dengan kemandirian ekonomi. Menurut Irine Herdjiono dan Lady Angela Damanik (2016) yang dikutip dari Kholilah dan Iramani (2013), financial knowledge adalah penguasaan seseorang atas berbagai hal tentang dunia keuangan. Pengetahuan keuangan meliputi pengetahuan umum keuangan pribadi, tabungan dan pinjaman, asuransi, dan investasi.

Financial Behaviour menurut Irine Herdjiono dan Lady Angela Damanik (2016) dikutip dari Kholilah dan Iramani (2013), financial behaviour adalah kemampuan seseorang melakukan perencanaan, penganggaran, pemeriksaan, pengelolaan, pengendalian, pencarian dan penyimpanan dana keuangan sehari-hari. Perilaku keuangan seseorang dapat dilihat dari empat hal, yaitu konsumsi, manajemen arus kas, menabung dan berinvestasi, serta manajemen utang.

Menurut Irine Herdjiono dan Lady Angela Damanik (2016) dalam Pankow (2003), mendefinisikan financial attitudes sebagai keadaan pikiran, pendapat serta penilaian tentang keuangan. Menurut Furnham (1984) yang dikutip Irine Herdjiono dan Lady Angela Damanik (2016), financial attitudes tercermin dalam enam konsep berikut yaitu (1) Obsession, merujuk pada pola pikir seseorang tentang uang dan persepsinya tentang masa depan untuk mengelola uang dengan baik; (2) Power, yaitu merujuk pada seseorang yang menggunakan uang sebagai alat untuk mengendalikan orang lain dan menurutnya uang dapat menyelesaikan masalah; (3) Effort, merujuk pada seseorang yang merasa pantas memiliki uang dari apa yang sudah dikerjakannya; (4) Inadequacy, merujuk pada seseorang yang selalu merasa tidak cukup memiliki uang; (5) Retention, merujuk pada seseorang yang memiliki kecenderungan tidak ingin menghabiskan uang; dan (6) Security, merujuk pada pandangan seseorang yang sangat kuno tentang uang seperti anggapan bahwa uang lebih baik hanya disimpan sendiri tanpa ditabung di Bank atau untuk investasi.

\section{Usaha Mikro Kecil dan Menengah (UMKM)}

Menurut Undang-Undang No. 20 Tahun 2008, UMKM terdiri dari usaha mikro, usaha kecil, dan usaha 
menengah. Usaha mikro adalah usaha produktif milik orang perorangan dan/atau badan usaha perorangan yang memenuhi kriteria usaha mikro sebagaimana yang diatur dalam undang-undang ini. Sedangkan usaha kecil adalah usaha ekonomi produktif yang mandiri, yang dilakukan oleh orang perseorangan atau badan usaha yang bukan merupakan anak perusahaan atau cabang perusahaan yang dimiliki, dikuasai, atau menjadi bagian baik langsung maupun tidak langsung dan usaha menengah atau usaha besar yang memenuhi kriteria usaha kecil sebagaimana dimaksud dalam undang-undang ini. Usaha menengah adalah usaha ekonomi produktif yang mandiri yang dilakukan oleh perseorangan atau badan usaha yang bukan merupakan anak perusahaan atau cabang perusahaan yang dimiliki, dikuasai, atau menjadi bagian baik langsung maupun tidak langsung dengan usaha kecil atau usaha besar dengan jumlah kekayaan bersih atau hasil penjualan tahunan sebagaimana diatur dalam undangundang ini.

Badan Pusat Statistik mendefinisikan UMKM berdasarkan jumlah tenaga kerja, yang mana usaha mikro mempunyai jumlah tenaga kerja kurang dari 5 orang, usaha kecil memiliki jumlah tenaga kerja sebanyak 5-19 orang, dan usaha menengah memiliki jumlah tenaga kerja sebanyak 20-99 orang.

Kriteria UMKM menurut UU No. 20 Tahun 2008 diantaranya usaha mikro memiliki kekayaan bersih paling banyak Rp 50.000.000 (tidak termasuk tanah dan bangunan tempat usaha) dan memiliki omset sebesar Rp 300.000.000 per tahun. Usaha kecil memiliki kekayaan bersih minimal $\mathrm{Rp}$ 50.000 .000 dan maksimal Rp 500.000.000 (tidak termasuk tanah dan bangunan tempat usaha) serta omset penjualan sebesar Rp 300.000.000 - Rp 2.500.000.000 per tahun. Sedangkan usaha menengah memiliki kekayaan bersih sebesar Rp 500.000.000 - Rp 10.000.000.000 (tidak termasuk tanah dan bangunan tempat usaha) dan omset penjualan tahunan sebesar $\mathrm{Rp}$ 2.500.000.000 - Rp 50.000.000.000.

Selain berdasarkan UU No. 20 Tahun 2008, kriteria UMKM berdasarkan sudut pandang perkembangannya dikelompokkan menjadi empat jenis, yaitu livelihood activities, mikro enterprise, small dynamic enterprise, dan fast moving enterprice. Lifelihood activities merupakan UKM yang digunakan sebagai kesempatan kerja untuk mencari nafkah, yang lebih umum dikenal sebagai sektor informal, seperti pedagang kaki lima. Micro enterprise, merupakan UKM yang baru memiliki sifat pengrajin tetapi belum memiliki sifat kewirausahaan. Small Dynamic Enterprise, merupakan UKM yang telah memiliki jiwa kewirausahaan dan mampu menerima pekerjaan subkontrak dan ekspor. Fast moving enterprise, merupakan UKM yang telah memiliki jiwa kewirausahaan dan bersiap melakukan transformasi menjadi usaha besar.

Menurut Peraturan Gubernur DKI No. 33 Tahun 2010, pedagang kaki lima adalah kegiatan usaha jasa perdagangan yang menempati prasarana kota, fasilitas sosial, dan fasilitas umum milik pemerintah daerah, tanah atau lahan milik perorangan atau badan yang telah mendapat izin dari gubernur atau kepala daerah. Jenis lokasi usaha mikro pedagang kaki lima terdiri dari lokasi binaan usaha mikro pedagang kaki lima, lokasi sementara usaha mikro pedagang kaki lima, lokasi usaha pedagang tanaman hias dan batu alam, 
lokasi pujasera UKM, lokasi terjadwal usaha mikro pedagang kaki lima, dan lokasi usaha terkendali usaha mikro pedagang kaki lima.

Sarana dan fasilitas lokasi binaan usaha mikro pedagang kaki lima terdiri dari lahan tempat usaha terbuka, setengah tertutup atau tertutup yang dilengkapi dengan fasilitas sarana MCK, listrik, tempat sampah, dan papan nama lokasi.

\section{Perkembangan Usaha UMKM}

Pengembangan

UMKM

seringkali mengalami keterlambatan. Hal ini disebabkan berbagai masalah konvensional yang tidak terselesaikan secara tuntas, seperti masalah kapasitas SDM, kepemilikan, pembiayaan, pemasaran dan berbagai masalah lain yang berhubungan dengan pengelolaan usaha, sehingga UMKM sulit bersaing dengan perusahaan-perusahaan besar (Abor dan Quartey, 2010).

Menurut hasil penelitian Manurung dan Barlian (2012), UMKM di industri kreatif cenderung memiliki orientasi jangka pendek dalam pengambilan keputusan bisnisnya. Hal ini terlihat dari tidak adanya konsep inovasi yang berkelanjutan dan aktivitas inti bisnis yang tidak konsisten. Pada akhirnya, perkembangan kinerja jangka panjang UMKM industri kreatif cenderung stagnan dan tidak terarah.

UMKM cenderung memiliki ketahanan atau kinerja yang stabil di tengah perubahan iklim bisnis dan ekonomi. Kinerja UMKM dapat dianalisis dengan menggunakan pendekatan yang didasarkan pada tiga asumsi, yaitu pengukuran kinerja UMKM kerap sulit dilakukan secara kuantitatif, dikarenakan terbatasnya sumber daya (pemahaman keuangan dan tenaga kerja), pengukuran kinerja pada umumnya melihat indikator keuangan yang kompleks, sehingga hal ini tidak secara lengkap memperlihatkan kondisi aktual yang terjadi pada bisnis tersebut, dan pengukuran kinerja yang kerap dipakai relatif hanya sesuai bila digunakan untuk perusahaan besar yang terstruktur dengan baik manajemen perusahaannya (Ali, 2003).

Pendekatan

non-cost

performance measures untuk mengukur kinerja UMKM sebagai pengukuran kinerja keuangan dan non keuangan UMKM. Metode pengukuran yang mudah, melalui persepsi, diharapkan mampu memperlihatkan kondisi sebenarnya dari UMKM tersebut, selain ke depan perlu dilakukan edukasi untuk menghitung kinerja perusahaan dengan indikator yang mudah seperti company's growth, company's total revenue (sales), total orders dan cash position (Dwitya Aribawa, 2016).

Perkembangan usaha UMKM dapat dilihat dari beberapa indikator yang dikeluarkan oleh Bank Indonesia, diantaranya indikator keuangan (meliputi modal, aset, dan omset), indikator pemasaran, dan indikator SDM.

Tingkat literasi keuangan yang baik memberikan kemudahan bagi pelaku usaha (UMKM) dalam mengakses pemodalan dari lembaga keuangan baik khususnya yang berprinsip syariah. Selain itu akan dapat meningkatkan kemampuan UMKM dalam pengelolaan keuangan yang akan berdampak pada perkembangan usahanya yang ditandai dengan meningkatnya pendapatan, volume penjualan, peningkatan laba usaha, dan meningkatnya permintaan, meningkatnya pemodalan yang tidak hanya ersumber dari modal sendiri tetapi modal yang berasal dari pinjaman atau pembiayaan dari 
lembaga keuangan. Hal tersebut sejalan dengan hasil penelitian Dwitya Aribawa (2016), bahwa literasi keuangan berpengaruh terhadap kinerja dan keberlanjutan usaha pada UMKM kreatif di Jawa Tengah. UMKM memiliki kecenderungan untuk mengatasi keterbatasan yang melekat padanya sehingga UMKM kooperatif dalam menjalankan bisnisnya untuk saling melengkapi keterbatasan dan memperoleh keunggulan kompetitif yang spesifik untuk mampu bersaing di lingkungan global.

Penciptaan nilai tambah pada aspek financial seperti meningkatnya modal, pendapatan, dan laba, meningkatnya jumlah sumber daya manusia (SDM) atau karyawan, meningkatnya keahlian yang dimiliki seperti keahlian memasarkan, keahlian mengelola modal, serta meningkatnya keahlian untuk berinovasi menciptakan berbagai produk yang berkualitas.

\section{Kajian Literatur dan Pengembangan Hipotesis}

Terdapat beberapa penelitian terdahulu yang mengukur dan menganalisis tingkat literasi keuangan, namun masih sedikit penelitian yang mengukur dan menganalisis tingkat literasi keuangan syariah. Diantara penelitian-penelitian tersebut diantaranya adalah:

Rose Abdullah dan Ahmad Lutfi Abdul Razak (2015) melakukan penelitian dengan judul "Exploratory Reseach Into Islamic Financial Literacy in Brunei Darussalam" penelitian ini secara garis besar menyimpulkan bahwa rendahnya literasi keuangan syariah berakibat pada rendahnya kesadaran untuk membayar zakat, terutama zakat maal. Rendahnya literasi keuangan syariah masyarakat Brunei Darussalam juga berdampak pada rendahnya akses masyarakat pada produk-produk keuangan syariah, seperti saham syariah, obligasi syariah, takaful dan produk-produk keuangan syariah lainnya. Mohamad Azmi Abdullah dan Rosita Chong (2014) juga melakukan penelitian terkait dengan literasi keuangan syariah dengan judul "Financial Literacy : An Exploratory Review of Literature and Future Reseach" yang menyimpulkan bahwa dengan semakin berkembangnya institusi-institusi dan produk-produk keuangan syariah berdampak cukup signifikan pula terhadap tingkat literasi keuangan syariah masyarakat Malaysia. Berdasarkan kajian literaturliteratur sebelumnya maka hipotesis yang dapat dikembangkan adalah:

H1 : Tingkat Literasi Keuangan Syariah di kalangan UMKM masih rendah berada pada rentang less literate hingga sufficient literate.

Penelitian Zara Fathia Muflihani dan Irfan Syauqi Beik yang berjudul Tingkat Literasi Pelaku Usaha Mikro terhadap Perbankan Syariah pada tahun 2015. Metode penelitian menggunakan kuantitatif. Hasil penelitian menunjukkan bahwa $40 \%$ responden memiliki tingkat literasi yang rendah, $28,57 \%$ responden memiliki tingkat literasi sedang, dan $31,43 \%$ memiliki tingkat literasi tinggi. Tingkat literasi perbankan syariah dapat mempengaruhi sikap responden terhadap lembaga perbankan syariah. Semakin tinggi literasi masyarakat terhadap perbankan syariah maka semakin memudahkan upaya mengajak masyarakat lainnya untuk menjadi nasabah perbankan syariah (Jurnal Iqtishodia, 2015).

Penelitian Isnurhadi yang berjudul Determinan Tingkat Literasi Masyarakat terhadap Perbankan Syariah (Studi Kasus: Masyarakat Kota Palembang) pada tahun 2013. 
Penelitian ini menggunakan metode kuantitatif. Hasil penelitian menunjukkan bahwa pengetahuan individu terhadap muamalah di dalam Islam dan upaya promosi yang dilakukan perbankan syariah berpengaruh terhadap literasi masyarakat terhadap perbankan syariah, sedangkan promosi oleh pemerintah tidak berpengaruh (eprints.unsri.ac.id, 2013).

Siti Hafidzah Abdul Rahim (2015) melakukan penelitian berjudul Psychological Factors and Gender Influencing The Level of Islamic Financial Literacy. Penelitian ini menilai tingkat literasi keuangan Islam di kalangan mahasiswa S1 Keuangan dan Perbankan Syariah di Universitas Utara Malaysia. Tujuan penelitian adalah untuk menguji faktor psikologis seperti ketidakberdayaan, religiusitas, kepuasan keuangan dan gender terhadap literasi keuangan syariah. Hasil penelitian menunjukkan bahwa tingkat literasi keuangan Islam di kalangan responden (mahasiswa) tinggi. Perbedaan yang signifikan dalam literasi keuangan Islam ditemukan antara responden menurut jenis kelamin (gender) dan lamanya masa studi, bahwa laki-laki nemiliki tingkat literasi keuangan Islam yang lebih tinggi dibandingkan perempuan, sementara mahasiswa tingkat tiga memiliki tingkat literasi keuangan Islam yang lebih tinggi dibandingkan mahasiswa tingkat satu dan dua. Hasil penelitian diperoleh hubungan yang signifikan antara faktor psikologis, ketidakberbayaan, religiusitas, dan gender terhadap literasi keuangan Islam.

Berdasarkan kajian literaturliteratur sebelumnya maka hipotesis yang dapat dikembangkan adalah:

$\mathrm{H} 2$ : Tingkat literasi keuangan syariah dipengaruhi oleh faktor gender, usia, lamanya usaha, tingkat pendidikan, dan tingkat pendapatan.

Penelitian Dwitya Aribawa yang berjudul Pengaruh Literasi Keuangan terhadap Kinerja dan Keberlangsungan UMKM di Jawa Tengah pada tahun 2016. Penelitian ini menggunakan model persamaan struktural untuk menganalisis data. Hasil penelitian menunjukkan bahwa terdapat pengaruh literasi keuangan terhadap kinerja dan keberlangsungan UMKM di Jawa Tengah. Adanya literasi keuangan yang baik diharapkan UMKM akan memiliki kemampuan membuat keputusan manajemen dan keuangan yang tepat untuk meningkatkan kinerja dan keberlangsungan UMKM (Jurnal Siasat Bisnis, 2016).

Penelitian Adib Agusta yang berjudul Analisis Deskriptif Tingkat Literasi Keuangan pada UMKM di Pasar Koga Bandar Lampung tahun 2016. Penelitian ini menggunakan metode deskriptif. Hasil penelitian menunjukkan bahwa tingkat literasi keuangan di Pasar Koga Bandar Lampung termasuk kategori well literate, tingkat gender dan tingkat pendidikan menunjukkan adanya pengaruh dalam meningkatkan literasi keuangan. Akun yang dimiliki para pelaku UMKM di pasar Koga Bandar Lampung didominasi oleh produk perbankan (Skripsi, 2016).

Berdasarkan kajian literaturliteratur sebelumnya maka hipotesis yang dapat dikembangkan adalah:

H3 : Tingkat literasi keuangan syariah berpengaruh signifikan terhadap perkembangan usaha UMKM.

Penelitian Rike Setiawati yang berjudul Literasi Keuangan Islam (Suatu telaah Literatur). Metode telaah yang digunakan adalah review sistematis yang bersumber dari berbagai rujukan jurnal yang berupa penelitian empiris dan kajian 
konseptual. Hasil penelitian menunjukkan bahwa penelitian literasi keuangan umumnya menemukan kondisi yang masih relatif rendah dilihat dari penggunaan akses di sektor keuangan formal maupun informal. Kondisi literasi keuangan Indonesia yang relatif rendah ini didukung adanya tingkat kemiskinan yang relatif tinggi namun berbanding terbalik dengan pertumbuhan industri perbankan syariah dan aktivitas pasar modal syariah telah menunjukkan kemajuan. Artinya, kehadiran institusi tersebut yang seharusnya mendorong pergerakan ekonomi syariah, tetapi sejauh ini hanya melayani masyarakat yang feasible dan bankable, serta relatif belum menjangkau masyarakat golongan miskin yang mayoritas muslim. Sementara penelitian literasi keuangan saat ini masih terbatas pada lingkup masyarakat kelas menengah dan atas, belum menjangkau lapisan terbesar pembentuk iliterasi yaitu lapisan chronic poor. (jurnalreturn.stiealkhairiyah.ac.id).

Perbedaan penelitian yang akan dilakukan dengan penelitian sebelumnya adalah bahwa penelitian tentang literasi keuangan syariah ini akan mengukur tingkat literasi sekaligus pengaruhnya terhadap preferensi, dan penelitian diperdalam dengan adanya kajian pada aspek implikasinya bagi lembaga keuangan syariah.

\section{Metode Penelitian}

Pendekatan penelitian yang digunakan pada penelitian ini adalah penelitian deskriptif dan verifikatif. Terdapat dua jenis data yang digunakan dalam peneltian, yaitu data primer dan sekunder. Data primer terdiri dari observasi, wawancara, dan pengumpulan data di lapangan melalui kuesioner sebagai alat pengumpulan atau yang pokok. Data sekunder berupa publikasi yang terkait dengan topik penelitian dan desk study.

Metode penelitian yang digunakan adalah: deskriptive survey dan explanatory survey. Objek penelitian adalah variabel yang akan diteliti dalam hal ini adalah tingkat literasi keuangan dan variabel-variabel yang mempengaruhinya serta dampaknya terhadap perkembangan UMKM. Subjek pada penelitian ini adalah UMKM (pedagang) di kawasan Masjid Raya At-Taqwa Cirebon yang berjumlah 31 responden. Pengambilan sampel dilakukan menggunakan sampel jenuh, yaitu seluruh populasi diambil sebagai sampel.

Pengamatan menggunakan cakupan waktu "one shoot"/cross sectional yaitu kurang dari satu tahun. Jangka waktu penelitian akan dilakukan selama 6 bulan yaitu Bulan Juni sampai Bulan November 2017. Penelitian dilakukan di kawasan Masjid Raya At-Taqwa Kota Cirebon.

Teknik pengumpulan data dengan menyebarkan kuesioner yang disusun menggunakan skal likert dari 1 hingga 4, skala 1 berarti sangat tidak benar, skala 2 berarti tidak benar, skala 3 artinya benar, skala 4 artinya sangat benar.

Untuk mendapatkan gambaran tingkat literasi keuangan syariah di kalangan UMKM (pedagang), faktorfaktor yang menentukan tingkat literasi dan untuk mendapatkan gambaran bagaimana pengetahuan tentang keuangan syariah yang dimiliki mempengaruhi perkembangan usaha yang dijalankan, maka digunakan pendekatan deskriptif dan verifikatif. Pengukuran dan analisis deskriptif tersebut kemudian digunakan sebagai dasar untuk melakukan analisis statistik. Di sini akan dicoba diidentifikasi faktor demografi dalam 
menentukan tingkat literasi keunagan syariah melalui model analisis regresi berganda (multivariate regression analysis). Faktor demografi yang diteliti adalah lokasi usaha, usia, jenis kelamin, pendidikan, jenis usaha, lama usaha, modal awal, sumber modal, pendapatan, dan jumlah karyawan.

Tingkat literasi keuangan syariah dihitung berdasarkan mean atau rata-rata dari setiap pertanyaan survey dan mengelompokkannya ke dalam empat kategori. UMKM dengan skor 3 $\leq \mathrm{x} \leq 4$ diklasifikasikan sebagai UMKM yang memiliki literasi keuangan syariah yang baik (well literate), UMKM dengan skor $2 \leq \mathrm{x} \leq 3$ diklasifikasikan sebagai UMKM yang memiliki literasi keuangan syariah yang cukup (sufficient literate), UMKM dengan skor $1 \leq \mathrm{x} \leq 2$ diklasifikasikan sebagai UMKM yang memiliki literasi keuangan syariah yang kurang (less literate), dan UMKM dengan skor $1 \leq \mathrm{x}$ diklasifikasikan sebagai UMKM yang tidak memiliki literasi keuangan syariah (not literate).

Pada penelitian ini dilakukan pengujian instrumen untuk memastikan apakah alat ukur yang digunakan valid dan reliabel. Kemudian dilakukan juga uji asumsi klasik untuk memastikan bahwa model memenuhi kriteria BLUE (Best Linear Unbiased Estimator). Uji asumsi klasik yang dilakukan diantaranya uji normalitas, uji heterokedastisitas, uji multikolinearitas, dan uji autokorelasi. Model verifikatif yang digunakan pada penelitian ini menggunakan teknik regresi linear berganda (multivariate linear regression) untuk melihat pengaruh jumlah variabel independen $\mathrm{X}_{1}, \mathrm{X}_{2}, \ldots . \mathrm{X}_{\mathrm{k}}$ terhadap variabel dependen $\mathrm{Y}$ yang merupakan variabel independen. Ditetapkan $\alpha=0,1$ sebagai taraf kesalahan yang dapat ditolerir.

Persamaan regresi linear berganda pada penelitian ini adalah:

$$
\begin{aligned}
& \mathrm{y}=\beta_{0}+\beta_{1} x_{1}+\beta_{2} x_{2}+\beta_{3} x_{3}+ \\
& \beta_{4} x_{4}+\beta_{5} x_{5}+\beta_{6} x_{6}+\beta_{7} x_{7}+ \\
& \beta_{8} x_{8}+\beta_{9} x_{9}+\beta_{10} x_{10}+e
\end{aligned}
$$

Dimana $\beta_{0}$ adalah intersep dan $\beta_{j} ; \mathrm{j}=1$ sampai dengan 10 adalah parameter terkait dengan variabel $\mathrm{j}$. Sedangkan $e$ adalah error term (disturbances) yang merupakan penampung faktor lain yang tidak tercakup dalam model, seperti kesalahan fungsional, kesalahan pengukuran, dan sebagainya. Parameter $\beta_{j}(\mathrm{i}=1,2,3, \ldots, 10)$ menunjukkan besaran hubungan antara variabel bebas ke i dengan variabel terikat, dengan mengasumsikan seluruh faktor lain (yang tercakup dalam $e$ ) sebagai konstan.

\section{Hasil Penelitian \\ Tingkat Literasi Keuangan Syariah}

Pengolahan data kuesioner yang disebar kepada 31 responden menghasilkan angka rata-rata literasi keuangan syariah sebesar 2,04. Angka tersebut menunjukkan bahwa tingkat literasi keuangan syariah di kalangan pedagang sektor non formal di kawasan masjid Raya At-Taqwa termasuk dalam kategori less literate.

Menurut hasil survey sebelumnya yang dilakukan Otorisasi Jasa Keuangan (OJK) less literate berarti pedagang hanya memiliki pengetahuan tentang lembaga jasa keuangan syariah, produk keuangan syariah, dan jasa keuangan syariah.

\section{Analisis Deskriptif}

Pada penelitian ini diperoleh data dari 31 responden, terdiri dari pedagang yang memiliki lokasi usaha 
di dalam lingkungan masjid Raya AtTaqwa dan di sekitar masjid yang merupakan relokasi karena sebelumnya para pedagang tersebut berjualan di trotoar jalan Kartini di depan masjid At-Taqwa.

Berdasarkan pengolahan data, analisis deskriptif mengenai demografi responden sebagai berikut:

\section{Variabel Lokasi}

Lokasi pedagang dibagi menjadi dua lokasi, yaitu di dalam komplek masjid dan di sekitar masjid Raya AtTaqwa (relokasi). Hasil olah data secara deskriptif diperoleh gambaran tentang lokasi usaha pedagang dengan kode 1 (relokasi) berjumlah 27 pedagang $(87,1 \%)$ dan pedagang dengan kode 2 (di dalam lingkungan masjid At-Taqwa) berjumlah 4 pedagang $(12,9 \%)$. Hal ini menunjukkan bahwa lebih banyak pedagang yang memilki lokasi usaha di sekitar masjid At-Taqwa yang merupakan relokasi.

\section{Variabel Usia}

Usia pedagang dibagi menjadi tiga kategori, yaitu pedagang berusia kurang dari 20 tahun, pedagang berusia antara 20-30 tahun, dan pedagang berusia lebih dari 30 tahun. Berdasarkan hasil olah data deskriptif diperoleh gambaran bahwa tidak ada pedagang yang berusia kurang dari 20 tahun, dan pedagang berusia 20-30 tahun berjumlah 4 pedagang $(12,9 \%)$, sedangkan pedagang berusia lebih dari 30 tahun berjumlah 27 pedagang $(87,1 \%)$.

\section{Variabel Jenis Kelamin}

Responden pada penelitian ini terdiri dari laki-laki dan perempuan. Berdasarkan hasil olah data deskriptif diperoleh informasi bahwa pedagang laki-laki lebih sedikit dibanding perempuan, dengan rincian pedagang laki-laki berjumlah 15 orang $(48,4 \%)$, sedangkan pedagang perempuan berjumlah 16 pedagang $(51,6 \%)$.

\section{Variabel pendidikan}

Jenjang pendidikan pedagang dibagi menjadi enam kategori, yaitu pedagang yang tidak mengenyam pendidikan (tidak bersekolah), pedagang berpendidikan SD/sederajat, pedagang berpendidikan

SMP/sederajat, pedagang berpendidikan SMA/sederajat, pedagang berpendidikan diploma, dan pedagang berpendidikan sarjana. Berdasarkan hasil olah data deskriptif diperoleh gambaran bahwa pedagang yang tidak bersekolah sebanyak 2 orang $(6,5 \%)$, pedagang yang berpendidikan $\mathrm{SD} /$ sederajat berjumlah 7 orang (22,6\%), pedagang berpendidikan $\quad \mathrm{SMP} /$ sederajat berjumlah 5 orang $(16,1 \%)$, pedagang berpendidikan SMA/sederajat sebanyak 14 orang $(45,2 \%)$, tidak ada pedagang yang berpendidikan diploma, dan sisanya 3 orang pedagang $(9,7 \%)$ berpendidikan sarjana.

\section{Variabel Jenis Usaha}

Berdasarkan hasil olah data deskriptif diperoleh gambaran pedagang yang memiliki jenis usaha kuliner sebanyak 29 orang $(93,5 \%)$, tidak ada pedagang yang memiliki jenis usaha fashion, dan sebanyak 2 orang pedagang $(6,5 \%)$ memiliki jenis usaha lainnya. Pedagang di kawasan masjid Raya At-Taqwa didominasi oleh pedagang dengan jenis usaha kuliner. Usaha kuliner di Cirebon makin berkembang pesat seiring dengan makin banyaknya pendatang yang berkunjung ke Cirebon setelah dibukanya tol Cipali. Cirebon memiliki banyak makanan khas daerah (tradisional) sehingga kini Cirebon 
telah menjadi salah satu destinasi wisata kuliner bagi para pendatang.

\section{Variabel Lama Usaha}

Jumlah pedagang yang menjalankan usahanya kurang dari satu tahun berjumlah 5 orang $(16,1 \%)$, pedagang yang yang menjalankan usaha selama 1-3 tahun sebanyak 3 orang $(9,7 \%)$, dan pedagang yang telah menjalankan usahanya selama lebih dari 3 tahun sebanyak 23 orang (74,2\%). Artinya, kebanyakan pedagang di kawasan masjid raya AtTaqwa telah lama berdagang.

\section{Variabel Modal Awal}

Informasi yang diperoleh dari hasil survey adalah bahwa pedagang yang memulai usaha dengan menggunakan modal awal kurang dari Rp 1.000.000 berjumlah 13 orang $(41,9 \%)$, pedagang yang memulai usaha dengan modal awal sebesar Rp 1.000.000-Rp 3.000.000 sebanyak 8 orang $(25,8 \%)$, dan pedagang yang memulai usaha dengan modal awal lebih dari Rp 3.000.000 sebanyak 10 orang $(32,3 \%)$. Hal ini menunjukkan bahwa kebanyakan pedagang di kawasan masjid raya At-Taqwa merupakan pedagang-pedagang mikro yang bermodal sangat kecil.

\section{Variabel Sumber Modal}

Modal usaha dapat bersumber dari pemilik usaha yang disebut modal sendiri dan modal yang berasal dari pinjaman (pembiayaan). Berdasarkan dua kategori pengelompokkan tersebut, maka didapatkan deskripsi bahwa pedagang yang memulai usahanya dengan modal sendiri berjumlah 28 orang $(90,3 \%)$ dan pedagang yang memulai usaha dengan dana yang berasal dari pinjaman (pembiayaan) sebanyak 3 orang $(9,7 \%)$ yang dapat digambarkan pada tabel dan grafik berikut. Informasi tersebut dapat diartikan bahwa mayoritas pedagang di kawasan masjid At-Taqwa memulai usaha dengan modal sendiri. Berdasarkan hasil observasi diperoleh informasi bahwasanya para pedagang tersebut tidak suka berutang, sehingga lebih memilih untuk berusaha dengan modal sendiri.

\section{Variabel Pendapatan}

Pendapatan pedagang-pedagang tersebut dikelompokkan ke dalam tiga kategori, yaitu kelompok pertama adalah pedagang yang menghasilkan pendapatan kurang dari Rp 500.000 per hari, kelompok kedua adalah pedagang yang memperoleh pendapatan per hari antara Rp 500.000 hingga $\mathrm{Rp}$ 1.000.000, dan kelompok ketiga adalah pedagang yang menghasilkan pendapatan lebih dari Rp 1.000.000 per hari. Pedagang yang memiliki tingkat pendapatan kurang dari Rp 500.000 per hari sebanyak 24 orang $(77,4 \%)$, pedagang dengan tingkat perolehan pendapatan sebanyak Rp 500.000-Rp 1.000 .000 sebanyak 6 orang $(19,4 \%)$, dan pedagang yang memperoleh pendapatan lebih dari Rp 1.000.000 per hari hanya ada 1 orang $(3,2 \%)$.

\section{Variabel Jumlah Karyawan}

Analisis deskriptif mengenai jumlah karyawan yang dimiliki oleh para pedagang di kawasan masjid AtTaqwa yang dikelompokkan menjadi dua kategori, yaitu pedagang yang memiliki jumlah karyawan kurang dari 2 orang dan pedagang dengan jumlah karyawan lebih dari 2 orang.

Berdasarkan hasil survey, diperoleh informasi bahwa pedagang dengan jumlah karyawan kurang dari 2 orang berjumlah 26 pedagang $(83,9 \%)$ dan pedagang dengan jumlah karyawan lebih dari 2 orang sebanyak 5 pedagang $(16,1 \%)$. Artinya, sebagian besar 
pedagang di kawasan masjid At-Taqwa mengelola sendiri usaha dagangnya karena skala usahanya yang masih kecil.

\section{Uji Instrumen Penelitian}

\section{Uji Validitas dan Reliabilitas}

Pengujian validitas dilakukan untuk mengetahui aspek kecermatan pengukuran sehingga alat ukur yang digunakan dapat mendeteksi perbedaan-perbedaan kecil yang ada pada atributnya. Berdasarkan hasil olah data seluruh item pernyataan dinyatakan valid.

Pengujian reliabilitas dilakukan untuk mengukur tingkat konsistensi dan kemantapan alat ukur. Reliabilitas adalah sejauh mana pengukuran dari suatu tes tetap konsisten setelah dilakukan berulang-ulang terhadap subjek dan dalam kondisi yang sama. Penelitian dianggap dapat diandalkan bila memberikan hasil yang konsisten untuk pengukuran yang sama. Berdasarkan hasil pengujian, seluruh variabel dinyatakan reliabel.

\section{Uji Asumsi Klasik}

Model regresi linier berganda (multiple regression) dapat disebut sebagai model yang baik jika model tersebut memenuhi kriteria BLUE (Best Linear Unbiased Estimator). BLUE dapat dicapai bila memenuhi asumsi klasik. Sedikitnya terdapat empat uji asumsi yang harus dilakukan terhadap suatu model regresi tersebut, yaitu uji normalitas, uji autokorelasi, uji multikolinieritas, dan uji heteroskedastisitas.

\section{Uji Normalitas}

Berdasarkan pengujian normalitas untuk variabel X1-X10 terhadap Y1, uji normalitas X1-X10 terhadap Y2, uji normalitas X1-X10 terhadap Y3, dan uji normalitas Y1-Y3 terhadap Z, semua data terdistribusi normal karena dari semua gambar terlihat sebaran titik-titik mendekati atau rapat pada garis (diagonal).

\section{Uji Heterokedastisitas}

Pengujian heterokedastisitas dilakukan dengan membuat scatterplot (alur sebaran) antara residual dan nilai prediksi dari variabel terikat yang telah distandarisasi. Sebaran titik tidak membentuk pola atau alur tertentu, sehingga dapat disimpulkan tidak terjadi heterokedastisitas. Asumsi klasik tentang heterokedastisitas dalam model ini terpenuhi, yaitu terbebas dari heterokedastisitas.

\section{Uji Multikolinearitas}

Model regresi linear yang baik adalah yang terbebas dari adanya multikolinearitas. Pada semua tabel terlihat nilai VIF untuk seluruh variabel $<5$ sehingga dapat dikatakan tidak terjadi multikolinearitas pada seluruh variabel bebas.

\section{Uji Autokorelasi}

Tabel

Durbin_Watson menunjukkan bahwa nilai $\mathrm{dL}=0,741$ dan nilai $\mathrm{dU}=2,333$ sedangkan nilai DW hitung adalah DW hitung $1=$ 1,823 , DW hitung $2=1,854$, DW hitung $3=2,069$, dan DW hitung $4=$ 1,908, sehingga dapat disimpulkan bahwa nilai DW hitung seluruhnya lebih besar dari dL dan lebih kecil dari $\mathrm{dU}$, maka dapat disimpulkan bahwa dalam model regresi linear tidak terjadi autokorelasi.

\section{Analisis Regresi Berganda}

Berikut adalah hasil olah data statistik yang menggambarkan korelasi (hubungan) variabel demografi responden $\left(\mathrm{X}_{1}-\mathrm{X}_{10}\right)$ terhadap variabel financial knowledge $\left(\mathrm{Y}_{1}\right)$. 
Tabel Model Summary

\begin{tabular}{|l|r|r|r|r|}
\hline Model & \multicolumn{1}{|c|}{ R } & R Square & Adjusted R Square & Std. Error of the Estimate \\
\hline 1 &, $683^{\mathrm{a}}$ &, 467 &, 200 & 4,84506 \\
\hline
\end{tabular}

a. Predictors: (Constant), Jumlah_Karyawan, JK, Sumber_Modal, Jenis_Usaha, Lama_Usaha, Usia, Pendapatan, Modal_Awal, Pendidikan, Lokasi

Menurut Tabel di atas diperoleh informasi angka $R$ sebesar 0,683 menunjukkan bahwa korelasi antara variabel lokasi, usia, jenis kelamin, pendidikan, jenis usaha, lama usaha, modal awal, sumber modal, pendapatan, dan jumlah karyawan dengan financial knowledge adalah kuat. Besarnya angka Adjusted $R$ Square adalah 0,200. Angka tersebut menunjukan besarnya pengaruh variabel lokasi, usia, jenis kelamin, pendidikan, jenis usaha, lama usaha, modal awal, sumber modal, pendapatan, dan jumlah karyawan terhadap variabel financial knowledge adalah 20\%. Sisanya sebesar $80 \%$ dipengaruhi faktor lain.

Tabel ANOVA ${ }^{\text {a }}$

\begin{tabular}{|ll|r|r|r|r|r|}
\hline \multicolumn{1}{|l|}{ Model } & Sum of Squares & \multicolumn{1}{c|}{ df } & Mean Square & F & \multicolumn{1}{c|}{ Sig. } \\
\hline 1 & Regression & 411,282 & 10 & 41,128 & 1,752 &, $137^{\text {b }}$ \\
& Residual & 469,492 & 20 & 23,475 & & \\
Total & 880,774 & 30 & & & \\
\hline
\end{tabular}

a. Dependent Variable: Financial_Knowledge

b. Predictors: (Constant), Jumlah_Karyawan, JK, Sumber_Modal, Jenis_Usaha, Lama_Usaha, Usia, Pendapatan, Modal_Awal, Pendidikan, Lokasi

Tabel ANOVA diperoleh hasil uji $\mathrm{F}$ yang menunjukkan bahwa nilai $\mathrm{F}$ hitung sebesar 1,752 dan nilai Sig. sebesar 0,137 yang mana nilai Sig. Sebesar 0,137 lebih dari nilai alpha $0,05(5 \%)(1,137>0,05)$, sehingga dapat disimpulkan bahwa variabel lokasi, usia, jenis kelamin, pendidikan, jenis usaha, lama usaha, modal awal, sumber modal, pendapatan, dan jumlah karyawan secara simultan tidak berpengaruh terhadap variabel financial knowledge.

Berdasarkan Tabel Coefficient diketahui nilai signifikansi dari tiap variabel. Variabel lama usaha dan jumlah karyawan memiliki nilai Sig. < Alpha $0,05 \quad(5 \%)$ maka dapat disimpulkan variabel lama usaha dan jumlah karyawan secara signifikan berpengaruh terhadap variabel financial knowledge. Sedangkan variabel lokasi, usia, jenis kelamin, pendidikan, jenis usaha, modal awal, sumber modal, dan pendapatan memiliki nilai Sig. > Alpha 0,05 (5\%), maka dapat disimpulkan variabel lokasi, usia, jenis kelamin, pendidikan, jenis usaha, modal awal, sumber modal, dan pendapatan tidak berpengaruh terhadap variabel financial knowledge. 
Tabel Ringkasan Signifikansi Variabel $X_{1}-X_{10}$ terhadap Variabel $Y_{1}$

\begin{tabular}{|l|c|c|l|}
\hline \multicolumn{1}{|c|}{ Variabel } & Nilai Sig. & Nilai Alpha & \multicolumn{1}{c|}{ Keputusan } \\
\hline Lokasi & 0,246 & 0,05 & Tidak Berpengaruh \\
\hline Usia & 0,345 & 0,05 & Tidak Berpengaruh \\
\hline JK & 0,610 & 0,05 & Tidak Berpengaruh \\
\hline Pendidikan & 0,672 & 0,05 & Tidak Berpengaruh \\
\hline Jenis_Usaha & 0,433 & 0,05 & Tidak Berpengaruh \\
\hline Lama_Usaha & 0,009 & 0,05 & Berpengaruh \\
\hline Modal_Awal & 0,183 & 0,05 & Tidak Berpengaruh \\
\hline Sumber_Modal & 0,086 & 0,05 & Tidak Berpengaruh \\
\hline Pendapatan & 0,583 & 0,05 & Tidak Berpengaruh \\
\hline Jumlah_Karyawan & 0,037 & 0,05 & Berpengaruh \\
\hline
\end{tabular}

Berikut adalah hasil olah data variabel demografi $\left(\mathrm{X}_{1}-\mathrm{X}_{10}\right)$ terhadap statistik yang menggambarkan korelasi variabel financial behaviour $\left(\mathrm{Y}_{2}\right)$.

Tabel Model Summary

\begin{tabular}{|l|r|r|r|r|}
\hline Model & $\mathrm{R}$ & R Square & $\begin{array}{c}\text { Adjusted R } \\
\text { Square }\end{array}$ & $\begin{array}{l}\text { Std. Error of } \\
\text { the Estimate }\end{array}$ \\
\hline 1 &, $712^{\mathrm{a}}$ &, 508 &, 261 & 4,13079 \\
\hline
\end{tabular}

a. Predictors: (Constant), Jumlah_Karyawan, JK, Sumber_Modal, Jenis_Usaha, Lama_Usaha, Usia, Pendapatan, Modal_Awal, Pendidikan, Lokasi

Berdasarkan Tabel Model Summary diperoleh informasi mengenai angka $R$ sebesar 0,712 menunjukan bahwa korelasi antara variabel lokasi, usia, jenis kelamin, pendidikan, jenis usaha, lama usaha, modal awal, sumber modal, pendapatan, dan jumlah karyawan dengan Financial Behaviour adalah kuat. Besarnya angka Adjusted $R$

Square adalah 0,261. Angka tersebut menunjukan besarnya pengaruh variabel lokasi, usia, jenis kelamin, pendidikan, jenis usaha, lama usaha, modal awal, sumber modal, pendapatan, dan jumlah karyawan terhadap variabel financial behaviour adalah $26,1 \%$. Adapun sisanya sebesar $73,9 \%$ dipengaruhi oleh faktor lain.

Tabel ANOVA

\begin{tabular}{|ll|r|r|r|r|r|}
\hline \multicolumn{1}{|l|}{ Model } & Sum of Squares & \multicolumn{1}{c|}{ df } & Mean Square & F & Sig. \\
\hline 1 & Regression & 351.829 & 10 & 35.183 & 2.062 & $.081^{\text {a }}$ \\
& Residual & 341.268 & 20 & 17.063 & & \\
Total & 693.097 & 30 & & & \\
\hline
\end{tabular}

a. Dependent Variable: Financial_Behaviour

b. Predictors: (Constant), Jumlah_Karyawan, JK, Sumber_Modal, Jenis_Usaha, Lama_Usaha, Usia, Pendapatan, Modal_Awal, Pendidikan, Lokasi

Tabel ANOVA tersebut lebih dari nilai alpha $0,05 \quad(5 \%)$ menggambarkan hasil uji $F$ yang sehingga $(\mathbf{0 , 0 8 1}>\mathbf{0 , 0 5})$. Berarti dapat menunjukkan bahwa nilai $\mathrm{F}$ hitung disimpulkan bahwa variabel lokasi, sebesar 2,062 dan nilai Sig. sebesar usia, jenis kelamin, pendidikan, jenis 0,081. Nilai Sig. Sebesar 0,081 adalah usaha, lama usaha, modal awal, sumber 
modal, pendapatan, dan jumlah karyawan secara simultan tidak berpengaruh terhadap variabel financial behaviour.

Berdasarakan Tabel Coefficient diketahui nilai signifikansi dari tiap variabel yaitu, lokasi, usia, jenis kelamin, pendidikan, jenis usaha, lama usaha, modal awal, sumber modal, pendapatan, dan jumlah karyawan memiliki nilai Sig. > Alpha 0,05 (5\%), maka dapat disimpulkan variabel lokasi, usia, jenis kelamin, pendidikan, jenis usaha, lama usaha, modal awal, sumber modal, pendapatan, dan jumlah karyawan tidak berpengaruh terhadap variabel financial behaviour.

Ringkasan pengaruh signifikansi antara variabel demografi (lokasi, usia, jenis kelamin, pendidikan, jenis usaha, lama usaha, modal awal, sumber modal, pendapatan, dan jumlah karyawan) terhadap financial behaviour disajikan pada tabel berikut.

Tabel Ringkasan Signifikansi Variabel $\mathrm{X}_{1}-\mathrm{X}_{10}$ terhadap Variabel $\mathrm{Y}_{2}$

\begin{tabular}{|l|c|c|l|}
\hline \multicolumn{1}{|c|}{ Variabel } & Nilai Sig. & Nilai Alpha & \multicolumn{1}{c|}{ Keputusan } \\
\hline Lokasi & 0,133 & 0,05 & Tidak Berpengaruh \\
\hline Usia & 0,603 & 0,05 & Tidak Berpengaruh \\
\hline JK & 0,507 & 0,05 & Tidak Berpengaruh \\
\hline Pendidikan & 0,751 & 0,05 & Tidak Berpengaruh \\
\hline Jenis_Usaha & 0,965 & 0,05 & Tidak Berpengaruh \\
\hline Lama_Usaha & 0,488 & 0,05 & Tidak Berpengaruh \\
\hline Modal_Awal & 0,067 & 0,05 & Tidak Berpengaruh \\
\hline Sumber_Modal & 0,320 & 0,05 & Tidak Berpengaruh \\
\hline Pendapatan & 0,393 & 0,05 & Tidak Berpengaruh \\
\hline Jumlah_Karyawan & 0,072 & 0,05 & Tidak Berpengaruh \\
\hline
\end{tabular}

Selanjutnya adalah hasil olah korelasi (hubungan) variabel demografi data statistik yang menggambarkan responden $\left(\mathrm{X}_{1}-\mathrm{X}_{10}\right)$ terhadap variabel financial attitude $\left(\mathrm{Y}_{3}\right)$.

Tabel Model Summary

\begin{tabular}{l|l|r|r|r|}
\hline Model & $\mathrm{R}$ & R Square & $\begin{array}{c}\text { Adjusted R } \\
\text { Square }\end{array}$ & $\begin{array}{c}\text { Std. Error of } \\
\text { the Estimate }\end{array}$ \\
\hline 1 & $.486^{\mathrm{a}}$ & .236 & -.146 & 3.24419 \\
\hline a. Predictors: (Constant), Jumlah_Karyawan, JK, Sumber_Modal, \\
Jenis_Usaha, Lama_Usaha, Usia, Pendapatan, Modal_Awal, \\
Pendidikan, Lokasi
\end{tabular}

Angka $\quad R \quad$ sebesar $\quad 0,486$ menunjukan bahwa korelasi antara variabel lokasi, usia, jenis kelamin, pendidikan, jenis usaha, lama usaha, modal awal, sumber modal, pendapatan, dan jumlah karyawan dengan financial attitude adalah cukup kuat (sedang). Besarnya angka adjusted $R$ square adalah -0,146. Angka tersebut menunjukkan besarnya pengaruh variabel lokasi, usia, jenis kelamin, pendidikan, jenis usaha, lama usaha, modal awal, sumber modal, pendapatan, dan jumlah karyawan 
terhadap variabel financial attitude adalah $-14,6 \%$. Angka minus menunjukkan bahwa model tidak layak digunakan, variabel terlalu banyak dan data atau observasi terlalu sedikit.

Tabel ANOVA ${ }^{\mathrm{a}}$

\begin{tabular}{|ll|r|r|r|r|r|}
\hline Model & & Sum of Squares & \multicolumn{1}{c|}{ df } & Mean Square & F & Sig. \\
\hline 1 & Regression & 64.924 & 10 & 6.492 & .617 & $.782^{\mathrm{a}}$ \\
& Residual & 210.496 & 20 & 10.525 & & \\
& Total & 275.419 & 30 & & & \\
\hline
\end{tabular}

a. Dependent Variable: Financial_Attitude

c. Predictors: (Constant), Jumlah_Karyawan, JK, Sumber_Modal, Jenis_Usaha, Lama_Usaha, Usia, Pendapatan, Modal_Awal, Pendidikan, Lokasi

Hasil uji $F$ pada Tabel di atas menunjukkan bahwa nilai $\mathrm{F}$ hitung sebesar 0,617 dan nilai Sig. sebesar 0,782 . Berarti nilai Sig. sebesar 0,782 lebih dari nilai alpha $0,05 \quad(5 \%)$, sehingga $(0,782>0,05)$. Maka dapat disimpulkan bahwa variabel lokasi, usia, jenis kelamin, pendidikan, jenis usaha, lama usaha, modal awal, sumber modal, pendapatan, dan jumlah karyawan secara simultan tidak berpengaruh terhadap variabel financial attitude.
Berdasarakan Tabel dapat diketahui nilai signifikansi dari tiap variabel lokasi, usia, jenis kelamin, pendidikan, jenis usaha, lama usaha, modal awal, sumber modal, pendapatan, dan jumlah karyawan memiliki nilai Sig. > Alpha 0,05 (5\%), maka dapat disimpulkan variabel lokasi, usia, jenis kelamin, pendidikan, jenis usaha, lama usaha, modal awal, sumber modal, dan pendapatan tidak berpengaruh terhadap variabel financial attitude.

Tabel Ringkasan Signifikansi Variabel $\mathrm{X}_{1}-\mathrm{X}_{10}$ terhadap Variabel $\mathrm{Y}_{3}$

\begin{tabular}{|l|r|c|l|}
\hline \multicolumn{1}{|c|}{ Variabel } & Nilai Sig. & Nilai Alpha & Keputusan \\
\hline Lokasi & 0,821 & 0,05 & Tidak Berpengaruh \\
\hline Usia & 0,569 & 0,05 & Tidak Berpengaruh \\
\hline JK & 0,937 & 0,05 & Tidak Berpengaruh \\
\hline Pendidikan & 0,216 & 0,05 & Tidak Berpengaruh \\
\hline Jenis_Usaha & 0,870 & 0,05 & Tidak Berpengaruh \\
\hline Lama_Usaha & 0,131 & 0,05 & Tidak Berpengaruh \\
\hline Modal_Awal & 0,862 & 0,05 & Tidak Berpengaruh \\
\hline Sumber_Modal & 0,859 & 0,05 & Tidak Berpengaruh \\
\hline Pendapatan & 0,656 & 0,05 & Tidak Berpengaruh \\
\hline Jumlah_Karyawan & 0,313 & 0,05 & Tidak Berpengaruh \\
\hline
\end{tabular}

Berikutnya adalah hasil olah data statistik yang menggambarkan korelasi (hubungan) variabel literasi keuangan syariah yang terdiri dari financial knowledge $\left(\mathrm{Y}_{1}\right)$, financial behaviour $\left(\mathrm{Y}_{2}\right)$, dan financial attitude $\left(\mathrm{Y}_{3}\right)$ terhadap variabel perkembangan usaha UMKM (Z). 
Tabel Model Summary

\begin{tabular}{|l|r|r|r|r|}
\hline Model & R & R Square & \multicolumn{1}{|c|}{$\begin{array}{c}\text { Adjusted R } \\
\text { Square }\end{array}$} & $\begin{array}{c}\text { Std. Error of } \\
\text { the Estimate }\end{array}$ \\
\hline 1 & $.773^{\mathrm{a}}$ & .598 & .553 & 2.55810 \\
\hline
\end{tabular}

a. Predictors: (Constant), Financial_Attitude, Financial_Behaviour, Financial_Knowledge

Berdasarkan Tabel Model Summary diperoleh informasi mengenai angka $R$ sebesar 0,773 yang menunjukkan bahwa korelasi antara variabel financial knowledge, financial attitude, dan financial behaviour dengan perkembangan usaha UMKM adalah kuat. Besarnya angka Adjusted
$R$ Square adalah 0,553. Angka tersebut menunjukkan besarnya pengaruh variabel financial knowledge, financial attitude, dan financial behaviour dengan perkembangan usaha UMKM adalah 55,3\%. Adapun sisanya sebesar $44,7 \%$ dipengaruhi oleh faktor lain.

Tabel ANOVA ${ }^{\mathrm{a}}$

\begin{tabular}{|c|c|c|c|c|c|c|}
\hline \multicolumn{2}{|c|}{ Model } & Sum of Squares & Df & Mean Square & $\mathrm{F}$ & Sig. \\
\hline \multirow[t]{3}{*}{1} & Regression & 262.412 & 3 & 87.471 & 13.367 &, $000^{\mathrm{b}}$ \\
\hline & Residual & 176.685 & 27 & 6.544 & & \\
\hline & Total & 439.097 & 30 & & & \\
\hline
\end{tabular}

a. Dependent Variable: Perkembangan_Usaha

c. Predictors: (Constant), Financial_Attitude, Financial_Behaviour, Financial_Knowledge

Hasil uji $F$ pada Tabel ANOVA menunjukkan bahwa nilai $F$ hitung sebesar 13,367 dan nilai Sig. sebesar 0,000 yang artinya nilai Sig. Sebesar 0,000 kurang dari nilai alpha 0,05 $(5 \%)$, sehingga $(0,000<0,05)$. Maka dapat disimpulkan bahwa variabel financial knowledge, financial attitude, dan financial behaviour secara simultan berpengaruh terhadap perkembangan usaha UMKM.

Berdasarakan Tabel $\quad 4.25$ diketahui nilai signifikansi dari variabel financial Behaviour memiliki nilai Sig. sebesar $0,000<$ Alpha 0,05 (5\%), maka dapat disimpulkan bahwa variabel financial behaviour berpengaruh terhadap variabel perkembangan usaha. Sedangkan variabel financial knowledge dan financial attitude memiliki nilai Sig. > Alpha (5\%), maka dapat disimpulkan variabel financial knowledge dan financial attitude tidak berpengaruh terhadap variabel perkembangan usaha.

Ringkasan pengaruh signifikansi antara variabel literasi keuangan syariah (financial knowledge, financial behaviour, dan financial attitude) terhadap perkembangan usaha disajikan pada tabel berikut.

Tabel Ringkasan Signifikansi Variabel $\mathrm{Y}_{1}-\mathrm{Y}_{3}$ terhadap Variabel $\mathrm{Z}$

\begin{tabular}{|l|c|c|l|}
\hline \multicolumn{1}{|c|}{ Variabel } & Nilai Sig. & Nilai Alpha & \multicolumn{1}{c|}{ Keputusan } \\
\hline Financial Knowledge & 0,389 & 0,05 & Tidak Berpengaruh \\
\hline Financial Behaviour & 0,000 & 0,05 & Berpengaruh \\
\hline Financial Attitude & 0,098 & 0,05 & Tidak Berpengaruh \\
\hline
\end{tabular}


Berdasarkan pengujian statistik diperoleh hasil penelitian yang menunjukkan bahwa hanya variabel lama usaha dan jumlah karyawan yang berpengaruh signifikan terhadap financial knowledge. Artinya hampir

seluruh variabel demografi tidak mempengaruhi tingkat pemahaman atau literasi keuangan syariah para pedagang kaki lima sektor informal ini, hanya lamanya usaha dan jumlah karyawan saja yang berpengaruh terhadap literasi keuangan syariah di kalangan pedagang.

Hampir 99 persen, UMKM di Indonesia adalah usaha mikro di sektor informal dan pada umumnya menggunakan bahan baku lokal dengan pasar lokal. Itulah sebabnya UMKM tersebut tidak terpengaruh secara langsung oleh krisis global. Laporan World Economic Forum (WEF) 2010 menempatkan pasar Indonesia pada ranking ke-15. Hal ini menunjukkan bahwa Indonesia sebagai pasar yang potensial bagi negara lain. Potensi ini belum dimanfaatkan oleh UMKM secara maksimal (Sudaryanto, dkk., 2014).

Hasil pengujian statistik juga menginformasikan bahwa variabel demografi seluruhnya tidak berpengaruh signifikan terhadap financial behaviour dan financial attitude. Artinya seluruh variabel seperti lokasi, usia, jenis kelamin, pendidikan, jenis usaha, lama usaha, modal awal, sumber modal, pendapatan, dan jumlah karyawan tidak mempengaruhi perilaku dan sikap keuangan para pedagang kaki lima.

Pengujian statistik juga menunjukkan bahwa hanya financial behaviour (perilaku keuangan) saja yang mempengaruhi perkembangan usaha para pedagang kaki lima, sementara financial knowledge (pengetahuan keuangan) dan financial attitude (sikap keuangan) tidak mempengaruhi perkembangan usaha. Hasil penelitian ini berbeda dengan penelitian sebelumnya yang dilakukan oleh Dwitya Aribawa (2016) bahwa literasi keuangan mempengaruhi kinerja dan keberlanjutan usaha pada UMKM kreatif di Jawa Tengah. UMKM memiliki kecenderungan untuk mengatasi keterbatasan yang melekat padanya sehingga UMKM kooperatif dalam menjalankan bisnisnya untuk saling melengkapi keterbatasan dan memperoleh keunggulan kompetitif yang spesifik untuk mampu bersaing di lingkungan global.

Saat observasi di lapangan didapatkan informasi bahwa umumnya para pedagang tidak mengetahui keberadaan lembaga keuangan syariah juga produk-produk maupun jasa yang ditawarkannya. Hal ini disebabkan kurangnya sosialisasi pihak lembaga keuangan syariah di kalangan pedagang non formal.

Selain itu didapatkan pula informasi bahwa para pedagang takut meminjam dana dari pihak lain untuk menambah modalnya, sehingga para pedagang ini hanya menggunakan modal sendiri yang jumlahnya rendah dan terkesan seadanya.Para pedagang sektor informal tersebut semuanya menjalankan bisnis perorangan secara tradisional, sehingga tidak menerapkan manajemen keuangan, manajemen pemasaran, dan manajemen SDM yang profesional. Hal ini diperkuat dengan hasil penelitian sebelumnya yang dilakukan oleh I Made Narsa, dkk. (2012), bahwa kendala utama yang dihadapi oleh UMKM selain minimnya modal adalah penerapan manajemen yang profesional. Sistem pembukuan UMKM selama ini umumnya sangat sederhana dan cenderung mengabaikan kaidah administrasi keuangan yang 
standar (baku). Padahal laporan keuangan yang akurat dan baku akan banyak membantu UMKM untuk mengembangkan bisnisnya secara kuantitatif dan kualitatif. Ikatan Akuntan Indonesia padahal sudah menyiapkan SAK (Standar Akuntansi Keuangan) untuk UMKM yang dinamakan dengan SAK- ETAP (Entitas Tanpa Akuntabilitas Publik) yang resmi diberlakukan efektif sejak 1 Januari 2011. Kenyatannya, UMKM tidak memiliki laporan keuangan sesuai dengan standar SAK-ETAP dan UMKM yang memiliki catatan keuangan yang baik mempunyai perkembangan yang lebih pesat dibanding UMKM lainnya meskipun usia pendiriannya sama, bahkan lebih muda dari beberapa UMKM yang lainnya. Salah satu yang mendorong kemajuan UMKM adalah kemampuan mengakses kredit dari perbankan, sehingga masalah kesulitan permodalan dapat diatasi, bahkan omzet pun mengalami kenaikan.

\section{Penutup}

1. Tigkat literasi keuangan syariah di kalangan UMKM (pedagang) di Kawasan Masjid Raya At-Taqwa termasuk kategori less literate.

2. Faktor-faktor yang mempengaru literasi keuangan syariah di kalangan UMKM (pedagang) di kawasan Masjid Raya At-Taqwa diantaranya lokasi, usia, jenis kelamin, pendidikan, jenis usaha, lama usaha, modal awal, sumber modal, pendapatan, dan jumlah karyawan. Tetapi hanya lamanya usaha dan jumlah karyawan yang mempengaruhi financial knowledge.

3. Diantara ketiga variabel literasi keuangan syariah yang diteliti, hanya financial behaviour yang memilki pengaruh signifikan terhadap perkembangan usaha pedagang.

\section{Daftar Pustaka}

Abdullah Rose dan Razak Abdul Haji Lutfi Ahmad. 2015. Exploratory Research into Islamic Financial Literacy in Brunei Darussalam. https://www.researchgate.net/pub lication/283225608 diunduh pada Rabu, 18 Oktober 2017

Abdullah, M.A. and Chong, R. 2014. Financial Literacy: An Explanatory Review of The Literature and Future Research. Journal of Emerging Economies and Islamic Research 2.3

Abor, J., dan P. Quartey. 2010. Issues in SME development in Ghana and South Africa. International Research Journal of Finance and Economics. 39 (6). 219-227.

Adib Agusta. 2016. Analisis Deskriptif Tingkat Literasi Keuangan pada UMKM di Pasar Koga Bandar Lampung. Skripsi

Ali, I. 2003. A Performance Measurement Framework for a Small and Medium Enterprise. Univerity of Alberta Dissertation.

Aribawa Dwitya. 2016. Pengaruh Literasi Keuangan terhadap Kinerja dan Keberlangsungan UMKM di Jawa Tengah. Jurnal Siasat Bisnis Vol. 20 No.1

Ariefianto Doddy Mochamad. 2012. Ekonometrika. Jakarta: Penerbit Erlangga

Chen, H., and Volpe, R. P. 1998. An Analysis of Personal Financial Literacy among College Students. Financial Services Review, 7(2), 107-128

Ghozali, I. 2009. Multivariate Analysis Application with SPSS Program. Diponegoro University Publisher Herdjiono Irine, Damanik Angela Lady. 2016. Pengaruh Financial 
Attitude, Financial Knowledge,

Parental Income terhadap

Financial Management

Behaviour. Jurnal Manajemen

Teori dan Terapan Tahun 9 No.3, Desember 2016

Isnurhadi. 2013. Determinan Tingkat

Literasi Masyarakat terhadap

Perbankan Syariah (Studi Kasus:

Masyarakat Kota Palembang). eprints.unsri.ac.id. diunduh pada Senin, 13 Maret 2017

Lusardi, Annamaria, and Peter, Tufano. 2009. Debt Literacy Financial Experiences, and Overindebtedness. No. W14808. National Bureau of Economic Research

Manurung, E.M., dan Barlian, I. 2012. From small to significant: Innovation process in smallmedium creative businesses. International Journal of Innovation, Management and Technology. 3(6). 788 - 792

Muflihani Fathia Zara dan Beik Syauqi Irfan. 2015. Tingkat Literasi Pelaku Usaha Mikro terhadap Perbankan Syariah. Jurnal Iqtishodia

Rahim Abdul Hafidzah, Siti. Psychological Factors and Gender Influencing The

Level of Islamic Financial Literacy. Universitas Utara Malaysia

Santoso, Singgih (2000). Buku Latihan SPSS Statistik Parametrik. Jakarta: PT Elex Media Komputindo
Setiawati Rike. Literasi Keuangan Islam (Suatu telaah Literatur). jurnalreturn.stiealkhairiyah.ac.id diunduh pada Sein, 13 Maret 2017

Sugiyono. 2010. Statistika Untuk Penelitian. Bandung: Penerbit Alfabeta

http://bi.go.id/id/umkm/penelitian/nasi onal/kajian/Pages/Pemetaan-danStrategi-Peningkatan-DayaSaing-UMKM-dalamMenghadapi-MasyarakatEkonomi-ASEAN-(2015)-danPasca-MEA-2025.aspx diunduh pada Senin, 13 Maret 2017

http://www.cnnindonesia.com/ekonomi /20161121122525-92-174080/ kontribusi-umkm-terhadap-pdbtembus-lebih-dari-60-persen/ diunduh pada Senin, 13 Maret 2017

http://www.jakarta.go.id/jakv1/produkh ukum/search/0/0/all/90/all/75 diunduh pada 8 November 2017

http://www.kemenperin.go.id/artikel/14 200/Kontribusi-UMKM-Naik diunduh pada Senin, 13 Maret 2017

http://www.ojk.go.id/id/kanal/edukasidan-perlindungan konsumen/ Pages/ Literasi-Keuangan.aspx diunduh pada Senin, 13 Maret 2017

http://www.perpustakaan.kemenkeu.go .id/FOLDERJURNAL/2014_kaji an_pkem_Strategi\%20Pemberda yaan\%20UMKM.pdf

Undang-Undang Nomor 20 Tahun 2008 